\title{
Evaluating Cross-National Variations in Under-Declared Wages in the European Union: an Exploratory Study
}

\author{
Colin C. Williams*
}

Management School, University of Sheffield, 219 Portobello, Sheffield S1 4DP, United Kingdom

\begin{abstract}
In recent years, there has been a growing recognition that some employers illegitimately under-declare employees' salaries by paying an undeclared ('envelope') wage in addition to their official declared salary. The aim of this paper is to evaluate critically the competing perspectives that variously explain the cross-national variations in the propensity of employers to under-declare wages to be: simply a legacy of under-development (modernisation perspective); due to high taxes, state corruption and burdensome regulations and controls (neo-liberal perspective), or a result of inadequate state intervention in work and welfare arrangements which leaves workers less than fully protected (structuralist perspective). Reporting the results of a 2007 Eurobarometer involving 26,659 face-to-face interviews across the 27 member states of the European Union (EU-27) to evaluate the prevalence, size and nature of envelope wage arrangements across the EU-27, this exploratory study reveals that envelope wages are more common, larger and more likely to be for regular work in poorer, more corrupt and less equal nations with lower levels of taxation, state intervention in the labor market, social protection and redistribution via social transfers. The paper concludes by discussing both the theoretical and policy implications.
\end{abstract}

Keywords: Informal employment, undeclared work, envelope wages, tax compliance, tax evasion, European Union.

\section{INTRODUCTION}

In recent years, a small emergent stream of literature on the 'dark side' of employment relations has begun to highlight the existence of an illicit wage practice whereby some formal employers under-declare the salaries of their formal employees in order to avoid their tax and social insurance obligations by paying them an undeclared ('envelope') wage in addition to their official declared wage [1-7]. The purpose of this paper is to conduct an exploratory analysis of the reasons for the cross-national variations in the propensity of employers to under-declare employees' salaries by analyzing the results of a 2007 Eurobarometer involving 26,659 faceto-face interviews across the 27 member states of the European Union (EU-27).

Reviewing the literature on envelope wages, employers are widely asserted to under-declare the salaries of their employees in order to evade their full social insurance and tax liabilities [8-10]. Consequently, it might be assumed that the major reason for any cross-national variations in the tendency of employers to under-declare salaries will be that social insurance and tax liabilities are higher in some nations than others and that the remedy is therefore to reduce these liabilities in those nations where they are higher in order to reduce the prevalence of envelope wages. In this paper, however, the intention is to evaluate critically this thesis that cross-national variations in the prevalence, size and nature of

*Address correspondence to this author at the Management School, University of Sheffield, 219 Portobello, Sheffield S1 4DP, United Kingdom; Tel: +44 114222 3476;

E-mail: C.C.Williams@sheffield.ac.uk envelope wages can be explained in terms of high taxes and burdensome regulations and controls.

Turning to the broader literature on wholly undeclared work, which examines paid employment not declared to the authorities for tax, social security and/or labor law purposes when it should be but is legal in all other respects [11], not only have the cross-national variations been explained to be a direct result of high taxes and burdensome regulations (a neo-liberal perspective) but also as a legacy of underdevelopment (a modernization perspective), or a result of inadequate state intervention in work and welfare arrangements which leaves workers less than fully protected (a structuralist perspective) $[12,13]$. Here, the intention is to evaluate critically the validity of these competing explanations when analyzing the cross-national variations in underdeclared waged employment across the EU-27. Is it simply the case that the prevalence and size of envelope wage payments are greater in countries with higher social insurance and tax liabilities and burdensome regulations, as neoliberals suggest? Is it a legacy of a lack of modernization and under-development? Or is the prevalence and size of envelope wage payments greater in countries where there is less state intervention in work and welfare arrangements leaving workers unprotected, as structuralists assert?

To answer these questions, the first section briefly reviews the current literature on the prevalence, size and nature of envelope wage payments followed by the various theoretical explanations for the cross-national variations in this illicit wage arrangement. To evaluate the validity of these rival explanations, the second section reports the methodology of the 2007 Eurobarometer survey here used to analyze the cross-national variations in the prevalence, size and na- 
ture of envelope wage payments and the validity of the competing perspectives in East-Central Europe. The third section will then report the descriptive findings and the fourth section evaluates the competing explanations. This will reveal that envelope wage payments are less common, smaller and more likely to be for extra work conducted rather than regular employment in wealthier, less corrupt and more equal societies and those with higher levels of taxation, intervention in the labor market, social protection and redistribution via social transfers. The outcome in the final section will be a call for a rejection of the argument that the cross-national variations in envelope wages are a result of social insurance and tax liabilities being higher in some nations than others. Instead, a new neo-modernization perspective will be proposed that combines the explanations of the modernization and structuralist perspectives followed by a discussion of the implications of this re-theorization for tackling underdeclared waged employment.

\section{EXPLAINING UNDER-DECLARED WAGES: A LIT- ERATURE REVIEW}

For many decades, it was widely assumed that employment was either declared or undeclared. Declared employment referred to paid work wholly declared to the state for tax, social security and labor law purposes, while the only difference about undeclared employment was that the paid work was wholly hidden from or unregistered by, the state for tax, social security and/or labor law purposes [14-16]. The idea that undeclared and declared employment were not mutually exclusive and that an employment relationship could be simultaneously both declared and undeclared was seldom considered. Since the turn of the millennium, however, this has been contested by an emergent body of literature that has begun to reveal in East-Central Europe how formal employers sometimes under-declare salaries by paying declared employees both an official declared salary as well as an additional undeclared salary, or what is termed an 'envelope wage' which is hidden from, or unregistered by, the state for tax and social security purposes. Such studies of the tendency of employers to pay envelope wages to their declared employees have been conducted in Estonia [17], Latvia [18-20], Lithuania [21, 22], Romania [23], Russia [24] and Ukraine $[25,26]$.

These studies range from small-scale qualitative surveys to more extensive surveys of particular nations. At one extreme is a study in Lithuania of one person receiving envelope wages from his formal employer, albeit a cause celebre, whilst another qualitative study in the city of Riga in Latvia is based on 15 face-to-face interviews. More extensive surveys, meanwhile, are a study of 600 households in three localities in Ukraine, and 313 households in three districts of the Russian city of Moscow. The only cross-national representative survey reports 900 interviews in Estonia, Latvia and Lithuania but was undertaken between 1998 and 2002 so was at an early stage in the post-Soviet transition process.

Despite their limitations, these studies nevertheless provide a strong rationale for further investigation of underdeclared employment. In Latvia, 20 per cent of declared employees in the private sector were found to have received an envelope wage from their formal employer [27]. In Ukraine, meanwhile, 30 per cent of all declared employees in the three localities reported receiving an envelope wage [28], whilst in Moscow survey this figure was 65 per cent and the size of the envelope wage ranged from 20 to 80 per cent of their gross wage packet [29]. In most cases, moreover, the finding is that such envelope wages were not paid for overtime or extra work conducted. Instead, envelope wages were on the whole paid to declared employees for their regular employment, with the official declared salary sometimes being paid to the level of the minimum wage and any additional wages paid as an undeclared envelope wage.

Examining the reasons for employers under-declaring the salaries of their employees, and as discussed above, the main rationale given to repeat is that they are seeking to evade their full social insurance and tax liabilities. Given this, it might be assumed that the reason for any cross-national variations in the tendency of employers to under-declare salaries will be that social insurance and tax liabilities are higher in some nations than others and that the remedy is therefore to reduce these liabilities in nations where they are higher in order to reduce the propensity to pay envelope wages. In this paper, however, the intention is to evaluate critically this thesis. Reviewing the wider literature on crossnational variations in undeclared employment, this explanation is an aspect of just one of three alternative theoretical explanations for the cross-national variations in undeclared employment. That is, a neo-liberal perspective argues that its prevalence is a direct result of high social insurance and tax liabilities and too much state interference in the free market which results in burdensome regulations and controls. A structuralist explanation, however, argues the inverse, namely that its pervasiveness is the result of inadequate levels of state intervention in work and welfare provision which leaves workers unprotected, whilst a modernization thesis purports that such a wage arrangement decreases as economies modernize and develop. Here, each is reviewed in turn.

\section{MODERNIZATION PERSPECTIVE}

Over the course of the twentieth century, an on-going belief was that economies would modernize and develop and that the declared economy would replace the undeclared economy, which was seen as a residue or remnant from some pre-modern economic system. The resultant belief, therefore, was that in less modern and developed economies the undeclared economy is more widespread and a signal of its 'backwardness' and 'under-development', whilst declared employment was seen to signal 'progress' and 'development' [30-33].

Applying this modernization thesis to understanding the cross-national variations in the propensity of employers to under-declare salaries, it can be suggested that in less developed economies, measured in terms of GDP per capita, personal purchasing power or the quality of state bureaucracy, there will be a higher prevalence of envelope wages, mostly paid for regular employment and that the portion of the total gross wage received as an envelope wage will be higher than in more developed economies. To explore its validity, the following hypothesis can be tested:

Hypothesis 1: that envelope wage payments are less prevalent, smaller and paid for extra work rather than regular employment in more modern developed economies. 


\section{NEO-LIBERAL PERSPECTIVE}

Based on the assumption that the main reason for employers using envelope wages is to reduce social insurance and tax liabilities, it might be suggested that the major reason for cross-national variations in the tendency of employers to under-declare salaries will be that social insurance and tax liabilities are higher in some nations than others. This has been advocated by those of a neo-liberal persuasion in relation to undeclared employment who view participants as making a rational economic decision to voluntarily exit the declared economy in order to avoid the high taxes, corruption in the state system and the burdensome regulations that increase the cost, time and effort associated with declared employment [34-40]. From this perspective, therefore, envelope wage payments would be explained to result from high taxes, corruption, over-regulation and state interference in the free market and in consequence, such a practice would be more prevalent in countries with higher taxes, corruption and levels of state intervention in work and welfare systems and the consequent solution would be to pursue tax reductions, reduce corruption and state interference in the free market in order to reduce such an illicit wage arrangement. To explore the validity of this neo-liberal explanation, therefore, the following hypothesis can be tested:

Hypothesis 2: that envelope wages are less prevalent, smaller and paid for extra work rather than regular employment in countries with lower tax rates, public sector corruption and levels of state interference in work and welfare.

\section{STRUCTURALIST PERSPECTIVE}

For structuralists meanwhile, the prevalence of undeclared work in economies is the result of too little rather than too much state intervention in work and welfare arrangements. Viewing the adoption of undeclared work as an inherent component of accumulation practices in late capitalism and a key facet of the downsizing, sub-contracting and outsourcing arrangements emerging under de-regulated global capitalism, such undeclared practices are seen to provide businesses with a production channel to attain flexible production, profit and cost reduction [41-45]. In this new regime of accumulation, in consequence, the fullemployment/comprehensive welfare state regime of the Fordist and socialist era is seen to be disappearing and a new post-Fordist and post-socialist regime of deregulation, liberalization and privatization is emerging [46-49].

Viewed through this structuralist lens, under-declared salaries can be thus seen as a by-product of the lack of state intervention in work and welfare provision. Consequently, this envelope wage practice would be more prevalent and the size of the payments would be smaller and more for extra work conducted in countries with relatively low levels of state intervention in work and welfare arrangements. The way to prevent employers paying envelope wages, therefore, would be to pursue greater state intervention in work and welfare arrangements. Consequently, to evaluate the validity of this structuralist explanation, the following hypothesis can be tested:

Hypothesis 3: that envelope wages are less prevalent, smaller and paid for extra work rather than regular employ- ment in countries with greater state intervention in work and welfare arrangements.

\section{METHODOLOGY: EXAMINING ENVELOPE WAGES IN THE EU-27}

To evaluate the cross-national variations in the prevalence, size and nature of envelope wage payments and the validity of the competing explanations for these variations, the 2007 Eurobarometer survey of undeclared work is here analyzed which is one of the only cross-national comparative studies of this phenomenon [50]. This involved 26,659 faceto-face interviews, 500 in the smaller nations and 1,500 interviews in the larger EU countries, using a multi-stage random (probability) sampling method, with sampling points drawn with probability proportional to population size and population density according to the Eurostats NUTS II (or equivalent) and the distribution of the resident population in terms of metropolitan, urban and rural areas. Further addresses (every nth address) were subsequently selected by standard 'random route' procedures from the initial address. At the household level, meanwhile, the 'closest birthday rule' was used to select a participant for interview.

This face-to-face interview adopted a graduated approach, commencing with attitudinal questions on participation in undeclared work, followed by questions on whether they had received undeclared goods and services. Questions then turned to the issue of whether those who were formal employees had received an additional envelope wage from their formal employer and finally, questions were asked regarding their supply of undeclared work. Given the focus here on envelope wages, attention is paid to the questions asked on this issue. Firstly, those who reported that they were formal employees were asked, 'Sometimes employers prefer to pay all or part of the regular salary or the remuneration for extra work or overtime hours cash-in-hand and without declaring it to tax or social security authorities. Did your employer pay you all or part of your income in the last 12 months in this way?'. Secondly, and in order to comprehend the nature of envelope wage payments, they were asked 'Was this income part of the remuneration for your regular work, was it payment for overtime, or both?'. Thirdly, they were asked to estimate the percentage of their gross yearly income from their main job received as an undeclared envelope wage and fourthly, whether they were happy to receive a portion of their salary as an envelope wage.

Although previous studies have described the findings of this Eurobarometer survey with regard to the commonality of envelope wage payments in East-Central Europe [51] as well as South-East Europe [52, 53] and the Baltic region [54], these have been purely descriptive reports. No attempt has been so far made to explain the cross-national variations in the prevalence, size and nature of envelope wage payments. Here, therefore, for the first time, the competing explanations set out above are critically evaluated.

To evaluate the validity of these competing theorizations, official Eurostat data sources have been used to provide statistical indicators of the various characteristics each theorization purports have an influence on envelope wage payments, such as the level of GDP per capita, tax rates, levels of social protection and redistribution via social transfers for 2007, the same year as the Eurobarometer survey [55-60]. The only 
indicators taken from unofficial sources are firstly, the perceptions of public sector corruption, taken from Transparency International's corruption perceptions index (CPI) for 2007 , which is a composite index of perceptions of public sector corruption which synthesizes 14 expert opinion surveys and scores nations on a $0-10$ scale, with zero indicating high levels and 10 low levels of perceived public sector corruption [61] and secondly, evidence on the quality of state bureaucracy taken from the International Country Risk Guide (ICRG) [62]. This ICRG uses a 0-4 scale to evaluate the quality of bureaucracy in a country where 4 is high and 0 is low. Countries with a high quality state bureaucracy have the strength and expertise to govern without drastic changes in policy or interruptions in government services, a bureaucracy that is autonomous from political pressure and an established mechanism for recruitment and training. Countries with low quality state bureaucracy are those in which a change of government is traumatic in terms of policy formulation and day-to-day administrative functions.

To evaluate hypothesis 1 that envelope wage payments are less prevalent, smaller and paid for extra work rather than regular employment in more modern developed economies, therefore, Eurostat data on GDP per capita and purchasing power standards (PPS) are analyzed along with the quality of the state bureaucracy as measured by the International Country Risk Guide (ICRG). To analyze hypothesis 2 that envelope wages are less prevalent, smaller and paid for extra work rather than regular employment in countries with lower tax rates, public sector corruption and levels of state interference in work and welfare, firstly, implicit tax rates (ITR) on labor are examined, which is a summary measure of the average effective tax burden on the income of employed labor. This is the sum of all direct and indirect taxes and employees' and employers' social contributions levied on employed labor income, which is then divided by the total compensation of employees. Secondly, total tax revenue (excluding social contributions) as a percentage of GDP is analyzed, which includes all taxes on production and imports, income and wealth, and capital taxes. Thirdly, to measure public sector corruption, Transparency International's 2007 Corruption Perceptions Index (CPI) is used.

To analyze the state interference aspect of hypothesis 2 and hypothesis 3 that envelope wages are less prevalent, smaller and paid for extra work rather than regular employment in countries with greater state intervention in work and welfare arrangements, the following indicators are used. Firstly, the level of state social protection expenditure (excluding old age benefits) as a proportion of GDP is analyzed. Secondly, level of state intervention in the labor market is analyzed, which is the level of spending on labor market interventions to correct disequilibria explicitly targeted at groups of the population with difficulties in the labor market can be analyzed, such as those who are unemployed, in employment but at risk of involuntary job loss, and inactive persons currently excluded from the labor force but who would like to join the labor market but are somehow disadvantaged. Thirdly, the proportion of the population at risk of poverty is analyzed, here defined as persons with an equivalized disposable income below the risk-of-poverty threshold, which is set at 60 per cent of the national median equivalized disposable income, after social transfers. Fourthly, how effective state intervention is at mitigating poverty using redistribution via social transfers is analyzed. tribution via social transfers is analyzed. Again defining the poverty level as the proportion of the population with an income below 60 percent of the national median income, and then analyzing the reduction in percentage points of poverty after social transfers, a measure is provided of the effectiveness of state redistribution. Fifth and finally, the level of equality in societies is analyzed by examining the inequalities in the distribution of income, measured by evaluating the ratio of total income (by which is meant equivalized disposable income) received by the 20 per cent of the population with the highest income (top quintile) to that received by the 20 per cent of the population with the lowest income (lowest quintile).

Here, and given the small sample size of 27 countries, this paper limits itself to an exploratory analysis of the relationship between the prevalence, size and nature of envelope wage payments and the various societal characteristics that competing theorizations assert are influential. That is, bivariate regression analyses are provided of the relationship between the prevalence, size and nature of envelope wage payments and the different characteristics fore-grounded by each explanation. To improve the explanatory potential, more advanced statistical techniques would be required which would perhaps require a larger sample than these 27 member states of the European Union. Nevertheless, and as will be shown, this exploratory study produces some meaningful findings regarding the validity of the different theoretical perspectives.

\section{RESULTS: ENVELOPE WAGES IN THE EU-27}

Of the 26,659 face-to-face interviews conducted in the 2007 Eurobarometer survey, 11,135 reported that they were in declared employment. Of these 11,135 declared employees, 616 (5.5 per cent) asserted that they received an envelope wage from their formal employer in addition to their official declared wage in the year prior to the survey. Extrapolating from this, the intimation is that 11.6 million (one in 18) of the 210 million declared employees in the EU had received an envelope wage in the year prior to the survey.

The prevalence, size and nature of envelope wage payments however, are not everywhere the same. As Table 1 displays, there are marked cross-national variations in the prevalence of envelope wage payments, ranging from 23 per cent of declared employees in Romania reporting that they have received an envelope wage in the 12 months prior to the survey to just 1 per cent of formal employees in countries such as Luxembourg, Malta and the United Kingdom. Indeed, envelope wage arrangements across the EU-27 appear to be more common in East-Central European countries. Although only 37 per cent of all declared employees surveyed were in East-Central European countries, 69 per cent of those reporting that they received envelope wages worked in these nations. Indeed, 50 per cent of all reported instances of envelope wages being paid are in just five countries, namely Bulgaria, Latvia, Lithuania, Poland and Romania.

It is similarly the case that the size of envelope wage payments, namely the proportion of the gross wage received as an envelope wage, is not everywhere the same. Although 25 per cent of the gross wage was received as an undeclared envelope wage by those receiving envelope wages across the EU-27 as a whole, there are marked variations in the propor- 
Table 1 Prevalence, Size and Nature of Envelope Wage Arrangements in the EU-27

\begin{tabular}{|c|c|c|c|c|c|c|c|}
\hline \multirow[b]{2}{*}{ Country } & \multirow{2}{*}{$\begin{array}{c}\text { No. of Formal } \\
\text { Employees } \\
\text { Surveyed }\end{array}$} & \multirow{2}{*}{$\begin{array}{l}\text { \% of Formal Em- } \\
\text { ployees Receiving } \\
\text { Envelope Wages }\end{array}$} & \multirow{2}{*}{$\begin{array}{l}\% \text { of Gross Income } \\
\text { Received as Envelope } \\
\text { Wages (Median) }\end{array}$} & \multicolumn{4}{|c|}{ Envelope Wage Paid for: } \\
\hline & & & & $\begin{array}{c}\text { Regular } \\
\text { Work }\end{array}$ & $\begin{array}{c}\text { Overtime/ } \\
\text { Extra Work }\end{array}$ & $\begin{array}{l}\text { Both Regular \& } \\
\text { Overtime Work }\end{array}$ & $\begin{array}{l}\text { Refusal or } \\
\text { don't know }\end{array}$ \\
\hline EU27 & 11,135 & 6 & 25 & 33 & 28 & 32 & 6 \\
\hline Romania & 452 & 23 & 86 & 49 & 9 & 41 & 2 \\
\hline Latvia & 492 & 17 & 46 & 44 & 18 & 36 & 1 \\
\hline Bulgaria & 415 & 14 & 30 & 48 & 16 & 34 & 2 \\
\hline Poland & 286 & 11 & 49 & 35 & 17 & 48 & 0 \\
\hline Lithuania & 423 & 11 & 43 & 42 & 11 & 47 & 0 \\
\hline Estonia & 399 & 8 & 19 & 38 & 17 & 31 & 14 \\
\hline Hungary & 333 & 8 & 15 & 25 & 46 & 25 & 4 \\
\hline Italy & 430 & 7 & 40 & 11 & 18 & 41 & 30 \\
\hline Slovakia & 506 & 7 & 17 & 45 & 39 & 16 & 0 \\
\hline Belgium & 398 & 6 & 12 & 15 & 70 & 10 & 5 \\
\hline Slovenia & 357 & 5 & 15 & 12 & 41 & 29 & 18 \\
\hline Spain & 362 & 5 & 13 & 16 & 42 & 26 & 16 \\
\hline Portugal & 392 & 4 & 30 & 19 & 19 & 31 & 31 \\
\hline Austria & 560 & 4 & 16 & 16 & 44 & 32 & 8 \\
\hline Cyprus & 186 & 4 & 10 & 14 & 57 & 29 & 0 \\
\hline Greece & 247 & 3 & 15 & 29 & 57 & 14 & 0 \\
\hline Czech Rep & 501 & 3 & 14 & 14 & 50 & 36 & 0 \\
\hline Sweden & 542 & 3 & 11 & 8 & 75 & 8 & 8 \\
\hline Finland & 440 & 3 & 10 & 40 & 30 & 30 & 0 \\
\hline Netherlands & 490 & 2 & 14 & 0 & 75 & 13 & 13 \\
\hline Ireland & 458 & 2 & 13 & 12 & 63 & 0 & 25 \\
\hline Denmark & 494 & 2 & 10 & 8 & 42 & 17 & 33 \\
\hline France & 483 & 1 & 40 & 17 & 50 & 33 & 0 \\
\hline Germany & 624 & 1 & 13 & 33 & 67 & 0 & 0 \\
\hline Luxembourg & 186 & 1 & 10 & 0 & 100 & 0 & 0 \\
\hline Malta & 152 & 1 & 10 & 100 & 0 & 0 & 0 \\
\hline UK & 527 & 1 & 10 & 14 & 72 & 14 & 0 \\
\hline
\end{tabular}

tion of the gross wage received as an envelope wage, ranging from 86 per cent in Romania to 10 per cent in the UK, Malta, Luxembourg and Finland. Using Spearman's rank correlation coefficient to evaluate the relationship, due to the non parametric nature of the data, the finding is that there is a strong correlation between the cross-national variations in the prevalence of envelope wages and the share of the gross wage that employees receive as an envelope wage $\left(r_{s}=-\right.$ $.570 * * *)$. In countries where under-declared salaries are a more common practice, those receiving envelope wages receive a higher proportion of their gross salary on an unde- clared basis than in countries where under-declared salaries are less prevalent.

Neither is the nature of envelope wage arrangements the same across the EU-27. As Table 1 reveals, across the EU-27 as a whole, some 33 per cent of those paid envelope wages receive it for their regular work, 28 per cent for overtime/extra work and 32 per cent for both their regular work and overtime/extra work. However, there are marked crossnational variations. In Romania for example, just 9 per cent of those receiving envelope wage payments are paid this additional undeclared wage for overtime/extra work con- 
Table 2. Relationship Between Prevalence, size and Nature of Envelope Wage Payments and the Broader Socio-Economic Environment: Bivariate Analyses Using Spearman's rank Correlation Coefficient $\left(r_{s}\right)$

\begin{tabular}{|c|c|c|c|}
\hline Socio-economic Characteristic & $\begin{array}{c}\text { Prevalence of Envelope Wages: \% of } \\
\text { Formal Employees Receiving Enve- } \\
\text { lope Wages in Prior 12 Months }\end{array}$ & $\begin{array}{c}\text { Size of Envelope wage Payments: } \\
\text { \% of Gross Income Received as } \\
\text { Envelope Wages }\end{array}$ & $\begin{array}{c}\text { Nature of Envelope Wage } \\
\text { Payments: \% Paid for Over- } \\
\text { time/Extra Work }\end{array}$ \\
\hline \hline GDP per capita & $-.748^{* * *}$ & $-.611^{* * *}$ & $.668^{* * *}$ \\
\hline Purchasing power standards (PPS) & $-.753^{* * *}$ & $-.653^{* * *}$ & $.699^{* * *}$ \\
\hline Bureaucratic quality & $-.708^{* * *}$ & $-.802^{* * *}$ & $.744^{* * *}$ \\
\hline Implicit tax rate on labor & -.002 & -.110 & .031 \\
\hline Total tax revenue & $-.509^{* * *}$ & $-.576^{* * *}$ & $.508^{* * *}$ \\
\hline Corruption Perceptions Index & $-.715^{* * *}$ & $-.731^{* * *}$ & $.592^{* * *}$ \\
\hline Social protection expenditure & $-.679^{* * *}$ & $-.524^{* * *}$ & $.639^{* * *}$ \\
\hline Labour market expenditure & $-.468^{* *}$ & $-.389^{* *}$ & $.435^{* *}$ \\
\hline \% at risk of poverty & $.699^{* * *}$ & $.667^{* * *}$ & $-.617^{* * *}$ \\
\hline Effectiveness of redistribution & $-.479^{* *}$ & $-.528^{* * *}$ & $.457^{* *}$ \\
\hline Inequalities in income distribution & $.394^{* *}$ & $.603^{* * *}$ & $-.463^{* *}$ \\
\hline
\end{tabular}

** significant at 0.05 level, $* * *$ significant at 0.01 level

ducted, meaning that the vast majority of envelope wage payments are paid for regular work, whilst in countries such as Luxembourg and Sweden, 100 per cent 75 per cent of envelope wages respectively are received for overtime or extra work conducted. Indeed, there is a strong correlation between the percentage of formal employees receiving envelope wage payments and the type of activity for which envelope wage payments are received $\left(\mathrm{r}_{\mathrm{s}}=-.811^{* * *}\right)$. In countries in which higher proportions of formal employees receive envelope wages, such envelope wage payments are more likely to be paid for their regular employment.

It might be assumed that those receiving envelope wage payments will be contented with this arrangement because they may receive higher wage packets than if the tax and social insurance contributions were deducted. However, only a third of all employees receiving envelope wages are happy receiving this kind of payment. Another third would prefer full declaration and the remaining one-third were either undecided or refused to answer the question. Contentment with receiving an envelope wage is greatest among those receiving it for extra work or overtime hours only. Those receiving it for their regular work, or for both their regular work and overtime hours, would in 90 per cent of cases prefer full declaration. This is because receiving an official formal wage lower than their actual wage curtails their entitlement to social security and pension payments as well as their ability to get credit and loans. Consequently, the decision to be paid envelope wages for regular employment does not appear to be a mutual decision jointly agreed by employers and employees together. These employees would prefer to receive their whole salary on a declared basis. The decision, therefore, appears to have been taken to do so by the employer. Indeed, these qualitative studies reveal that if employees at the recruitment stage refuse to accept this arrangement, they will not be offered the job.

\section{DISCUSSION}

How, therefore, can the cross-national variations in the prevalence, size and nature of envelope wage payments be explained? Is the prevalence and size of envelope wage payments lower and more likely to be for extra work in more developed economies as the modernization thesis suggests? Or is the prevalence and size of envelope wage payments greater and more likely to be for extra work conducted in countries with higher tax rates, greater public sector corruption and more burdensome regulations as neo-liberals suggest? Or conversely, is the prevalence and size of envelope wage payments smaller and more likely to be for extra work conducted rather than regular employment in countries with greater state intervention in work and welfare arrangements that protect workers? Here, each of the hypotheses will be evaluated in turn. This will allow conclusions to be reached on the validity of the modernization, neo-liberal and structuralist explanations regarding envelope wages.

\section{Evaluating the Modernization Thesis}

Evaluating the relationship between the cross-national variations in envelope wages and GDP per capita in 2007 (European Commission, 2011: Table 3), Table 2 reveals, using Spearman's rank correlation coefficient due to the nonparametric nature of the data, a strong statistically significant relationship between the cross-national variations in the prevalence $\left(\mathrm{r}_{\mathrm{s}}=-.748^{* * *}\right)$, size $\left(\mathrm{r}_{\mathrm{s}}=-.611^{* * *}\right)$ and nature $\left(\mathrm{r}_{\mathrm{s}}=.668^{* * *}\right)$ of envelope wages and the cross-national variations in the levels of GDP per capita. In countries with higher levels of GDP per capita, envelope wage payments are less prevalent, the proportion of gross income workers receive from envelope wage payments is smaller and such wages are more commonly received for extra work or overtime conducted rather than for their regular employment. 
Since GDP per capita as an indicator fails to recognize the differences in the cost of living across countries, purchasing power standards (PPS) are here evaluated as an additional indicator of the level of development. Again, a strong correlation is identified between PPS and not only the prevalence of envelope wages $\left(\mathrm{r}_{\mathrm{s}}=-.753^{* * *}\right)$ but also the proportion of income received via envelope wages $\left(\mathrm{r}_{\mathrm{s}}=-.653^{* * *}\right)$ and whether the payments are for overtime/extra work conducted $\left(\mathrm{r}_{\mathrm{s}}=.699^{* *}\right)$. The higher the PPS in a country, the less prevalent are envelope wage payments, the smaller is the proportion of the gross wage paid via envelope wages and the more likely is such a payment to be made for overtime/extra work conducted rather than for regular employment.

Another proxy indicator of modern developed economies is the quality of the state bureaucracy as measured by the International Country Risk Guide (ICRG). The finding is that a strong correlation exists between cross-national variations in the quality of the bureaucracy and the prevalence of envelope wage payments $\left(\mathrm{r}_{\mathrm{s}}=-.708^{* * *}\right)$, the size of the envelope wage payments $\left(\mathrm{r}_{\mathrm{s}}=-.802 * * *\right)$ and their nature $\left(\mathrm{r}_{\mathrm{s}}=.822 * * *\right)$. The higher the quality of state bureaucracy, the less prevalent are envelope wage payments, the smaller they are as a proportion of gross income and the more likely they are to be paid for overtime/extra work rather than for regular employment. As such, the modernization thesis is confirmed that more developed countries with higher levels of GDP per capita, PPS and better quality bureaucracies are economies in which envelope wages payments are less prevalent, smaller and mostly for extra work/overtime. Future research might examine whether these relationships hold when a wider range of countries are analyzed.

\section{Evaluating the Neo-Liberal Thesis}

Is the neo-liberal thesis also valid that cross-national variations in the prevalence, size and nature of envelope wages are related to high taxes, public sector corruption and state interference in the free market? To evaluate this, firstly the relationship between cross-national variations in underdeclared salaries and tax rates can be analyzed. To do this, cross-national variations in implicit tax rates (ITR) on labor are examined. No significant correlation is found between cross-national variations in the ITR on labor income and cross-national variations in the prevalence, size or nature of envelope wage payments $\left(\mathrm{r}_{\mathrm{s}}=-.002, \mathrm{r}_{\mathrm{s}}=-.110, \mathrm{r}_{\mathrm{s}}=.031\right.$ respectively).

Given this lack of evidence that envelope wage payments are driven by employers seeking to reduce tax liabilities, and will therefore be higher in countries with greater tax rates, another measure of tax rates is here introduced to see if its produces different results, namely total tax revenue (excluding social contributions) as a percentage of GDP. The result is that a strong statistically significant correlation is identified between cross-national variations in total tax revenue and not only the prevalence of envelope wages across countries $\left(\mathrm{r}_{\mathrm{s}}=-.509^{* * *}\right)$ but also the size of the envelope wage payments $\left(\mathrm{r}_{\mathrm{s}}=-.576^{* * *}\right)$ and the nature of envelope wage payments $\left(\mathrm{r}_{\mathrm{s}}=.508^{* * *}\right)$. However, it is not in the direction intimated by the neo-liberal perspective. The higher is the total tax revenue as a percentage of GDP in a country, the lower is the prevalence of envelope wage payments, the smaller is the proportion of the gross wage paid via envelope wages and the more likely are such payments to be made for overtime/extra work. No evidence, therefore, is found to support the neo-liberal thesis that envelope wages are a product of higher taxes. Instead, if anything, quite the inverse is identified. In countries with higher total tax revenues, envelope wages are less prevalent, smaller and conducted more for overtime.

Cross-national variations in envelope wages, however, are related to the differences in public sector corruption across nations. Using Transparency International's 2007 Corruption Perceptions Index (CPI), a strong correlation is identified between cross-national variations in the level of public sector corruption and the prevalence of envelope wage payments $\left(\mathrm{r}_{\mathrm{s}}=-.715^{* * *}\right)$, the size of the payments as a proportion of the gross wage $\left(\mathrm{r}_{\mathrm{s}}=-.731 * * *\right)$ and whether such payments are paid for overtime or for regular employment $\left(\mathrm{r}_{\mathrm{s}}=.592 * * *\right)$. The higher is the perceived level of public sector corruption in a country, the more prevalent are envelope wages, the higher is the proportion of gross income received through envelope wage payments and the more likely is it to be paid for regular employment rather than for overtime/extra work.

This evaluation of the neo-liberal thesis therefore finds no evidence that envelope wages are related to higher tax levels. Indeed, if anything, quite the opposite is the case. Greater levels of public sector corruption, however, are correlated with higher levels of envelope wage payments, as suggested by neo-liberals, and also with an increase in the proportion of one's gross wage received in the form of envelope wages and the proportion of envelope wages paid for regular work rather than for overtime. Is it also the case, therefore, that envelope wages are more prevalent in nations where there is greater state interference, as neo-liberals assert? Or is it that greater state intervention in work and welfare reduces the prevalence and size of envelope wages and makes them more likely to be paid for overtime rather than regular employment, as the structuralist perspective asserts?

\section{Evaluating the Structuralist Thesis}

To evaluate the relationship between cross-national variations in state intervention in work and welfare provision and envelope wages, various societal characteristics can be analyzed. Firstly, and examining the level of state social protection expenditure (excluding old age benefits) as a proportion of GDP, the finding is that the greater the level of social protection expenditure in a country, the lower is the prevalence of envelope wage payments $\left(\mathrm{r}_{\mathrm{s}}=-.679 * *\right)$, the smaller is the proportion of the wage packet received through envelope wages $\left(\mathrm{r}_{\mathrm{s}}=-.524 * * *\right)$ and the more likely are envelope wages to be received for overtime/extra work than for regular employment $\left(\mathrm{r}_{\mathrm{s}}=.639^{* * *}\right)$. This, therefore, supports the structuralist rather than neo-liberal thesis.

Are cross-national variations in envelope wages also correlated with variations in the level of state intervention in the labor market? A significant correlation is identified between the cross-national variations in the proportion of GDP spent on labor market policy measures and the crossnational variations in the prevalence of envelope wages $\left(r_{s}=-\right.$ $.468 *)$, size of envelope wage payments $\left(\mathrm{r}_{\mathrm{s}}=-.389 * *\right)$ and nature of envelope wage payments $\left(\mathrm{r}_{\mathrm{s}}=.435^{* * *}\right)$. Envelope wages are less prevalent, smaller and more likely to be paid 
less prevalent, smaller and more likely to be paid for extra work, the greater is the level of intervention in the labor market in a country.

There is also a strong relationship between the proportion of the population at risk of poverty across countries and the varying prevalence of envelope wage payments $\left(\mathrm{r}_{\mathrm{s}}=.699^{* * *}\right)$, the size of envelope wage payments $\left(\mathrm{r}_{\mathrm{s}}=.667^{* * *}\right)$ and the nature of the payments $\left(\mathrm{r}_{\mathrm{s}}=-.617^{* *}\right)$. The higher the proportion of the population at risk of poverty, the higher is the prevalence of envelope wage payments, the greater is the proportion of the gross wage that is received via envelope wages and the more likely it is to be paid for regular employment.

Envelope wages, however, are less prevalent and smaller and more likely to be paid for overtime rather than regular employment in countries that more effectively intervene to reduce the proportion of the population at risk of poverty, using social transfers. Analyzing this, a statistically significant correlation is identified: the more effective is state redistribution via social transfers in reducing poverty, the less prevalent are envelope wage payments $\left(\mathrm{r}_{\mathrm{s}}=-.479 * *\right)$, the smaller they are $\left(\mathrm{r}_{\mathrm{s}}=-.528^{* * *}\right)$ and the more likely they are to be paid for overtime $\left(\mathrm{r}_{\mathrm{s}}=.457^{* *}\right)$.

The outcome is that cross-national variations in envelope wage arrangements appear to be closely associated with the level of equality in societies as measured by inequalities in the distribution of income. A statistically significant correlation is identified between inequalities in the distribution of income and the prevalence of envelope wage payments $\left(\mathrm{r}_{\mathrm{s}}=.394 * *\right)$, the size of such payments $\left(\mathrm{r}_{\mathrm{s}}=.603 * * *\right)$ and the nature of the payments $\left(r_{s}=-.463^{* *}\right)$. The more equal is the society in terms of the distribution of income, the less prevalent are envelope wage payments, the smaller they are as a proportion of gross income and the more likely they are to be paid for overtime/extra work rather than for regular employment.

\section{CONCLUSIONS}

This paper has evaluated critically three competing explanations for the cross-national variations in envelope wages: the 'modernization' thesis that envelope wage payments decrease as economies develop; the 'neo-liberal' thesis that envelope wages are a direct result of high taxes, corruption and state interference and the 'structuralist' thesis that envelope wage payments result from inadequate levels of state intervention to protect citizens. To do so, an analysis has been undertaken of the cross-national variations in the prevalence, size and nature of envelope wages across the 27 member states of the European Union. The finding is that in more developed, less corrupt and more equal societies and countries with higher levels of taxation, state intervention in the labor market, social protection and effective redistribution via social transfers, envelope wage payments are less prevalent and when received constitute a smaller proportion of gross income and are more likely to be paid for overtime/extra work. This, as will now be discussed, has both theoretical and policy implications.

Examining the implications for theorizing cross-national variations in envelope wages, these findings suggest that across the EU-27, the neo-liberal thesis is not valid that cross-national variations in envelope wages are a product of high taxes and too much state interference. Instead, quite the opposite is the case. Confirming the structuralist perspective, it is in nations where there are higher levels of taxation, labor market intervention, social protection and effective redistribution via social transfers, that the prevalence of envelope wage payments are lower, smaller and mostly for overtime/extra work. It does remain the case, however, as the modernization thesis asserts, that in more developed economies measured in terms of GDP per capita, PPS and the quality of the bureaucracy, envelope wage payments are less prevalent, smaller and mostly for overtime/extra work, as do nations in which perceptions of public sector corruption are lower, as the neo-liberal thesis intimates.

Consequently, the clear theoretical lesson is that no one existing theoretical explanation suffices. Instead, a synthesis is required. A new 'neo-modernization' theorization is therefore here proposed. This recognizes the validity of the modernization thesis that GDP per capita, purchasing power standards and the quality of state bureaucracy, the neo-liberal argument that state corruption and the structuralist explanation that state intervention in labor markets and welfare provision are all strongly correlated with cross-national variations in the prevalence, size and nature of envelope wage payments. The neo-modernization thesis, therefore, asserts that envelope wages are less prevalent in developed, wealthier and more equal societies in which there exists a modern state bureaucracy with less public sector corruption possessing higher levels of taxation, state intervention in the labor market, social protection and effective redistribution via social transfers that provides protection to workers. Indeed, this neo-modernization thesis certainly explains the greater prevalence and size of envelope wage payments largely for regular employment in many East-Central European countries which are generally less wealthy and less equal societies with higher rates of public sector corruption and lower levels of taxation, labor market intervention, social protection and state redistribution via social transfers relative to Nordic and Western European countries. Whether this relationship holds both when other global regions are evaluated as well as when time-series data is analyzed for individual countries, could usefully be explored in future research.

This exploratory study also has clear policy implications for protecting workers from receiving under-declared salaries. It suggests that the pursuit of lower taxes and deregulation, as advocated by neo-liberals, is not the way forward. Instead, reducing this illicit wage arrangement requires a modernization of work and welfare by addressing public sector corruption, improving the quality of the bureaucracy and through raising taxation, intervention in the labor market, and higher expenditure on social protection, coupled with the introduction of effective redistribution via social transfers so as to construct more equal societies. Again, whether the same finding emerges regarding the changes required when other global regions are investigated, as well as whether it remains valid when time-series data is investigated for individual countries, requires further research.

In sum, a strong correlation has been identified between envelope wage payments and the modernization of work and welfare arrangements. If this paper stimulates research to further evaluate this relationship, then it will have achieved 
its objective. If it also leads to recognition and investigation of the broader modernization of work and welfare that is required to tackle such illicit wage arrangements, then it will have achieved its broader intention. What seems certain from this exploratory study, however, is that the neo-liberal remedy of decreasing taxes and minimizing state interference seems likely to only worsen the problem of illicit undeclared envelope wages, rather than ameliorate it.

\section{CONFLICT OF INTEREST}

The authors confirm that this article content has no conflicts of interest.

\section{ACKNOWLEDGEMENTS}

Declared none.

\section{REFERENCES}

[1] Williams CC. Envelope wages in Central and Eastern Europe and the EU. Eastern Eur Econ 2008; 20: 363-76.

[2] Williams CC. The commonality of envelope wages in Eastern European economies. Eastern Eur Econ 2009; 47: 37-52.

[3] Williams CC. Illegitimate wage practices in Central and Eastern Europe: a study of the prevalence and impacts of 'envelope wages'. Debatte: J Contemp Central and Eastern Europe 2009; 17: 65-83.

[4] Williams CC. Evaluating the extent and nature of envelope wages in the European Union: a geographical analysis. Eur Spat Res Policy $2009 ; 16: 115-29$.

[5] Williams CC. The prevalence of envelope wages in Europe. Employee Relations 2009; 31: 412-26.

[6] Williams CC, Fethi M, Kedir A. Illegitimate wage practices in southeast Europe: an evaluation of 'envelope wages'. Balkanistica 2011; 24: 237-62.

[7] Williams CC, Padmore J. Evaluating the prevalence and distribution of quasi-formal employment in Europe. Relat Ind-Ind Relat 2013; 68: 71-95.

[8] Hazans M. Latvia: working too hard? In: Vaughan-Whitehead D, Ed. Working and Employment Conditions in the new EU member states: convergence or diversity? Geneva: ILO-EU 2005; pp. 14163.

[9] Round J, Williams CC, Rodgers P. Corruption in the post-Soviet workplace: the experiences of recent graduates in contemporary Ukraine. Work Employ Soc 2008; 22: 149-66.

[10] Williams CC. Illegitimate wage practices in Eastern Europe: the case of envelope wages. J E Eur Manag Stud 2008; 13: 253-70.

[11] European Commission. Stepping up the fight against undeclared work $\operatorname{COM}(2007) 628$ final. Brussels: European Commission 2007.

[12] Williams CC, Round J. Rethinking the nature of the informal economy: some lessons from Ukraine. Int J Urban Region Res 2007; 31: 425-41.

[13] Williams CC, Round J. A critical evaluation of romantic depictions of the informal economy. Rev Soc Econ 2008; 66: 297-323.

[14] European Commission. Special Eurobarometer 284: undeclared work in the European Union. Brussels: European Commission 2007.

[15] ILO. Decent work and the informal economy. Geneva: International Labour Office 2002.

[16] Williams CC, Windebank J. Informal Employment in the advanced economies: implications for work and welfare. London: Routledge 2008.

[17] Meriküll J, Staehr K. Unreported employment and envelope wages in mid-transition: comparing developments and causes in the Baltic countries. Comp Econ Stud 2010; 52: 637-70.

[18] OECD. Labour Market and Social Policies in the Baltic Countries. Paris: OECD 2003.

[19] Sedlenieks K. Cash in an envelope: corruption and tax avoidance as an economic strategy in Contemporary Riga. In: Arnstberg K, Boren T, Eds. Everyday Economy in Russia, Poland and Latvia. Stockholm: Almqvist and Wiksell 2003, pp. 42-65.

[20] Žabko O, Rajevska F. Undeclared work and tax evasion: case of Latvia. Paper presented at colloquium of the Belgian Federal Serv- ice for Social Security on Undeclared Work. Brussels: Tax Evasion and Avoidance 2007.

[21] Karpuskiene V. Undeclared work, tax evasion and avoidance in Lithuania. Paper presented at colloquium of the Belgian Federal Service for Social Security on Undeclared Work. Brussels: Tax Evasion and Avoidance 2007.

[22] Woolfson C. Pushing the envelope: the 'informalization' of labor in post-communist new EU member states. Work Employ Soc 2007; 21: 551-64.

[23] Neef R. Aspects of the informal economy in a transforming country: the case of Romania. Int J Urban Region Res 2002; 26: 299-322.

[24] Williams CC, Round J. Beyond negative depictions of informal employment: some lessons from Moscow. Urban Studies 2007; 44 2321-38.

[25] Round J, Williams CC, Rodgers P. Corruption in the post-Soviet workplace: the experiences of recent graduates in contemporary Ukraine. Work Employ Soc 2008; 22: 149-66.

[26] Williams CC, Nadin S, Rodgers P. Evaluating competing theories of informal entrepreneurship: some lessons from Ukraine. Int J Entrepreneurial Behav Res 2012; 18(5): 528-43.

[27] OECD. Labour Market and Social Policies in the Baltic Countries. Paris: OECD 2003.

[28] Williams CC. Tackling undeclared work in Europe: lessons from a study of Ukraine. Eur J Industr Relat 2007; 13: 219-37.

[29] Williams CC, Round J, Rodgers P. The role of informal economies in the post-Soviet world: the end of transition? London: Routledge 2013.

[30] Geertz C. Old societies and new states: the quest for modernity in Asia and Africa. Glencoe, IL: Free Press 1963.

[31] Gilbert A. The Latin American City. London: Latin American Bureau 1998.

[32] Lewis A. The theory of economic growth. London: Allen and Unwin 1959.

[33] Packard T. Do workers in Chile choose informal employment? a dynamic analysis of sector choice. Washington DC: World Bank Latin American and the Caribbean Region Social Projection Unit 2007.

[34] Becker F. The informal economy. Stockholm: Swedish International Development Agency 2004.

[35] De Soto H. The other path. London: Harper and Row 1989.

[36] De Soto H. The Mystery of Capital: why capitalism triumphs in the West and fails everywhere else. London: Black Swan 2001.

[37] London T, Hart SL. Reinventing strategies for emerging markets: beyond the transnational model. J Int Bus Stud 2004; 35: 350-70.

[38] Nwabuzor A. Corruption and development: new initiatives in economic openness and strengthened rule of law. J Bus Ethics 2005; 59: $121-38$.

[39] Sauvy A. Le Travail Noir et l'Economie de Demain. Paris: Calmann-Levy 1984.

[40] Small Business Council. Small Business in the Informal Economy: making the transition to the formal economy. London: Small Business Council 2004.

[41] Davis M. Planet of slums. London: Verso 2006.

[42] Gallin D. Propositions on trade unions and informal employment in time of globalisation. Antipode 2001; 19: 531-49.

[43] Hudson R. Economic Geographies: circuits, flows and spaces. London: Sage 2005.

[44] Sassen S. Service employment regimes and the new inequality. In: Mingione E, Ed. Urban poverty and the underclass. Oxford: Basil Blackwell 1996; pp. 142-59.

[45] Slavnic Z. Political economy of informalization. European Societies 2010; 12: 3-23.

[46] Amin A, Cameron A, Hudson R. Placing the Social Economy. London: Routledge 2002.

[47] Castells M, Portes A. World underneath: the origins, dynamics and effects of the informal economy. In: Portes A, Castells M, Benton L, Eds. The informal economy: studies in advanced and less developing countries. Baltimore: John Hopkins University Press 1989; pp. 19-41.

[48] Fernandez-Kelly P. Introduction. In: Fernandez-Kelly P, Shefner J, Eds. Out of the Shadows: political action and the informal economy in Latin America. Pennsylvania: Pennsylvania State University Press 2006; pp.1-18.

[49] Meagher K. Identity Economics: social networks and the informal economy in Nigeria. New York: James Currey 2010. 
[50] TNS Infratest, Rockwool Foundation, Regioplan. Feasibility study on a direct survey about undeclared work VC/2005/0276. Brussels: European Commission 2006.

[51] Williams CC. Explaining undeclared wage payments by employers in Central and Eastern Europe: a critique of the neo-liberal deregulatory theory. Debatte: J Contemporary Cent Eastern Eur 2012; 20: 3-20.

[52] Williams CC. Beyond the formal/informal jobs divide: evaluating the prevalence of hybrid 'under-declared' employment in SouthEastern Europe. Int J Hum Res Manag 2010; 21: 2529-46.

[53] Williams CC. Cross-national variations in the under-reporting of wages in South-East Europe: a result of over-regulation or underregulation? South East Eur J Econ Bus 2012; 7: 53-61.

[54] Williams CC. The prevalence of envelope wages in the Baltic Sea region. Baltic J Manag 2009; 4: 288-300.

[55] European Commission. Employment and Social Developments in Europe 2011. Brussels: European Commission 2011.

[56] Eurostat. Taxation trends in the European Union: data for the EU member states and Norway. Brussels: Eurostat 2007.
[57] Eurostat. Taxation trends in the European Union: main results. Brussels: Eurostat 2010.

[58] Eurostat. GDP per capita in PPS. 2013. Available from: http://epp.eurostat.ec.europa.eu/tgm/table.do?tab=table\&init=1\&pl ugin $=1 \&$ language $=$ en $\&$ pcode $=$ tec 00114

[59] Eurostat. At risk of poverty rate by sex. 2013. Available from: http://epp.eurostat.ec.europa.eu/tgm/table.do?tab=table\&init=1\&pl ugin $=1 \&$ language $=$ en $\&$ pcode $=$ tsdsc 260

[60] Eurostat. Inequality of income distribution. 2013. Available from: http://epp.eurostat.ec.europa.eu/tgm/table.do?tab=table\&init=1\&pl ugin $=1 \&$ language $=$ en $\&$ pcode $=$ tessi0 10

[61] Transparency International. 2007 Corruption Perceptions Index (CPI) (available http://www.transparency.org/research/cpi/cpi 2007 (last accessed 12 May 2013)

[62] ICRG. International Country Risk Guide (ICRG). 2013. Available at: http://www.prsgroup.com/icrg.aspx (accessed 7 April 2013).

(C) Colin C Williams; Licensee Bentham Open.

This is an open access article licensed under the terms of the Creative Commons Attribution Non-Commercial License (http://creativecommons.org/licenses/by-nc/3.0/) which permits unrestricted, non-commercial use, distribution and reproduction in any medium, provided the work is properly cited. 